\title{
A new sensitive assay for measurement of cell-mediated cytotoxicity to intact layers of cultured human keratinocytes
}

\author{
Marleen M. De Bueger ${ }^{1}$, Cecile A.C.M. Van Els ${ }^{1}$, Johanna Kempenaar ${ }^{2}$, Maria Ponec ${ }^{2}$ \\ and Els Goulmy ${ }^{1}$ \\ Departments of ${ }^{\prime}$ Immunohaematology and Bloodbank and ${ }^{2}$ Dermatology, Untversity Hospital Leiden, Letden, The Netherlands \\ (Received 19 July 1989, revised received 3 October 1989 accepted 24 October 1989)
}

A cytotoxicity assay for sensitive measurement of cell-mediated lympholysis (CML) of human cultured keratınocytes (cK) is described The usage of ${ }^{51} \mathrm{Cr}$-labeled keratınocytes in intact layers as target cells in this assay allows objective and accurate determination of lysis of keratinocytes which have not undergone trypsin- and suspension-induced membrane changes Furthermore, the problem of high spontaneous ${ }^{51} \mathrm{Cr}$ release values encountered with suspended keratinocytes is overcome The assay was applied to study antigen-specific CML of cK by cloned cytotoxic T cells (CTL) and to determine the effect of IFN- $\gamma$ on the susceptibility of $\mathrm{cK}$ to lysis The results showed that HLA- $\mathrm{A}_{2}$ specific CTLs could reproducibly lyse cK of HLA-A $\mathrm{A}_{2}$ positive healthy skin donors both with and without incubation of cK with IFN- $\gamma$.

Applications of this keratınocyte cytotoxicity assay lie in determining the antigenic expression of human $\mathrm{cK}$, in analysis of effector cell/keratınocyte interactions in CML and of the modulatory effects of cytokines on these mechanisms The assay thus may provide a helpful tool in gaining insight into the role of CML of keratinocytes in the destruction of inflamed skin

Key words Cell-mediated lympholysıs assay, Cultured keratınocyte, Cytotoxıc T lymphocyte

\section{Introduction}

Cell-mediated lympholysis (CML) of keratınocytes (skin epidermal cells) may be one of the causes of skun destruction observed in various immunologic cutaneous diseases Immunofluores-

Correspondence to $M$ De Bueger, Department of $\mathrm{Im}$ munohaematology and Bloodbank, University Hospital Leiden, Rjunsburgerweg 10,2333 AA Leiden The Netherlands

Abbreviations CML, cell-mediated lympholysıs, CTL cyto toxic $\mathrm{T}$ lymphocyte, $\mathrm{K}$, human keratınocyte, $\mathrm{cK}$, cultured human keratınocyte $\mathrm{KM}$, keratınocyte culture medıum, E T, effector-to-target ratio, rIFN- $\gamma$, recombinant interferon- $\gamma$ ADCC antibody dependent cellular cytotoxicity, NK natural killer cell cence studies of infiltrated tissue, for example in graft versus host disease (Lampert et al, 1982, Guyotat et al, 1986), revealed $\mathrm{CD}^{+} \mathrm{T}$ cells in close association to degenerating keratmocytes, suggesting a possible role for cytotoxic $T$ cells (CTL) in the lysis of keratinocytes

In vitro, CML of human keratınocytes by sensitized CTL has been studied by only a small number of investigators (Bagot et al, 1985, Faure et al, 1985, Niederwieser et al, 1988, Kalısh, 1989) In all these studıes single cell suspensions of freshly isolated skin epidermal cells or of cultured keratinocytes (cK) obtamed by trypsinisdtion were used as target cells in the conventional ${ }^{51} \mathrm{Cr}$ release assay, as origmally described by 
Brunner (1968) There are several reasons however, why this assay may not to be optimal for measurement of CML of $\mathrm{cK}$ We found that suspended cK exhibited high values of spontaneous chromium leakage, which prevented accurate measurement of specific lysis In addition to this technical complication, cell suspensions of trypsinızed cK may form an in vitro target cell model with only limited value for assessing CML of keratinocytes in vivo Firstly, exposure of cK to trypsin is thought to induce rigorous membrane changes (Norris et al, 1985) Secondly, suspended cK, being deprived of anchorage, rapidly undergo terminal differentiation, marked by transformation of the extracellular matrix glycoproteins, which may affect the susceptibility of $\mathrm{cK}$ to lysis (Rheinwald et al, 1980) Norris (1985) systemat1cally compared the susceptibility of human $\mathrm{cK}$ in suspension versus those in intact layers to ADCC, NK activity and antibody-mediated lysis, using either ${ }^{51} \mathrm{Cr}$ release or fluorescein diacetate (FD) uptake as measure of lysis Exposure to trypsin rendered cK susceptible to NK activity, thereby indicating that the use of intact layers of $\mathrm{cK}$ is preferable for obtaining qualitative information on target cell determinants expressed on $\mathrm{cK}$ in vitro The FD uptake assay is a sensitive assay for assessment of lysis of cK in intact layers, however, this method is subjective and does not allow quantification as does, for example, a ${ }^{51} \mathrm{Cr}$-release assay (Norris et al, 1985) In our study we attempted to develop an assay in which intact layers of $\mathrm{cK}$ are used and which provides an objective and quantitative system to study effector cell/keratınocyte interactions

For that end, a modified ${ }^{51} \mathrm{Cr}$ release assay was devised in which ${ }^{51} \mathrm{Cr}$-labeled human $\mathrm{cK}$ as target cells are adherent to flat-bottomed 96-well microtiter plates Our data on the lysis of $\mathrm{cK}$ by alloHLA antigen-specific CTL clones indicate that this assay allows a reproducible read-out of $\mathrm{CML}$ of keratunocytes in vitro

\section{Materials and methods}

Human keratinocyte culture

Skin biopsies $\left(1 \mathrm{~cm}^{2}\right)$ were taken from the upper arms of healthy HLA-typed individuals Epidermal cells were isolated according to the method originally described by Liu and Karasek (1978) The resulting suspensions (97\% keratınocytes, 2-3\% Langerhans cells and melanocytes) were seeded together with irradiated 3T3 in culture flasks and cultured according to Rheinwald and Green (1975) in a humidified incubator at $37^{\circ} \mathrm{C}, 10 \% \mathrm{CO}_{2}$ Keratinocyte culture medium (KM) consisted of a 31 mixture of Dulbecco Vogt and Ham's F12 (Flow Laboratories), supplemented with $5 \%$ FCS (Flow), $10^{-6} \mathrm{M}$ 1soproterenol (Sigma), and $04 \mu \mathrm{g} / \mathrm{ml}$ hydrocortisone At day 4 , epidermal growth factor (10 $\mathrm{ng} / \mathrm{ml}$, Sigma) was added to the medium Cultures reached confluence after 7-10 days and, after trypsinization, cells were stored in hquid nitrogen until use in KM containing 6 6\% DMSO 8-9 days before use as target cells in the CML assay, the cryopreserved keratmocytes were thawed and subcultured as described above Confluence was reached after 6-7 days

\section{Preparation of keratinocyte layers}

2 days prior usage, confluent layers of $\mathrm{cK}$, cultured as described above, were washed two times with PBS of $37^{\circ} \mathrm{C}$ and harvested by trypsinization in $025 \%$ trypsin (Difco) in $\mathrm{Ca} / \mathrm{Mg}$-free PBS, supplemented with 005 M EDTA, $01 \%$ glucose, pH 75 After incubation for 20-30 mu at $37^{\circ} \mathrm{C}$, detached cells were suspended in $\mathrm{KM}$, counted and diluted to a concentration of $5 \times 10^{4}$ $\mathrm{cK} / \mathrm{ml}$ (unless stated otherwise) $200 \mu 1$ of the homogenous suspension (containing $10^{4} \mathrm{cK}$ ) was transferred to the wells of 96 well flat-bottomed microtiter plates (Greiner no 655160, unless stated otherwise) using a multichannel pipettor Cells were incubated for $36 \mathrm{~h}$ in a humified incubator $\left(37^{\circ} \mathrm{C}, 5 \% \mathrm{CO}_{2}\right)$ In those cases where the effect of IFN- $\gamma$ was studied, rIFN- $\gamma$ (Genentech, San Francisco, CA) was added to the wells during adhesion, ranging from 250 to $1000 \mathrm{U} / \mathrm{ml}, 16-48$ $\mathrm{h}$ Routinely the effect of a $20 \mathrm{~h}$ incubation of 250 $\mathrm{U} / \mathrm{ml}$ IFN $-\gamma$ was assesed Prior to ssotope labeling, non-adherent $\mathrm{cK}$ were removed by decantıng the $\mathrm{KM}$ and washing the cells with PBS at $37^{\circ} \mathrm{C}$ To each well, $100 \mu \mathrm{l}$ of $\mathrm{KM}$ containing $20 \mu \mathrm{Cl} / \mathrm{ml}$ ${ }^{51} \mathrm{Cr}$ (sodium chromate, $1 \mathrm{mCl} / \mathrm{ml}$, New England Nuclear, Boston, MA) was added After incubation for $15 \mathrm{~h}$ at $37^{\circ} \mathrm{C}$, the labeling flund was removed and the cells were washed three tum with PBS 


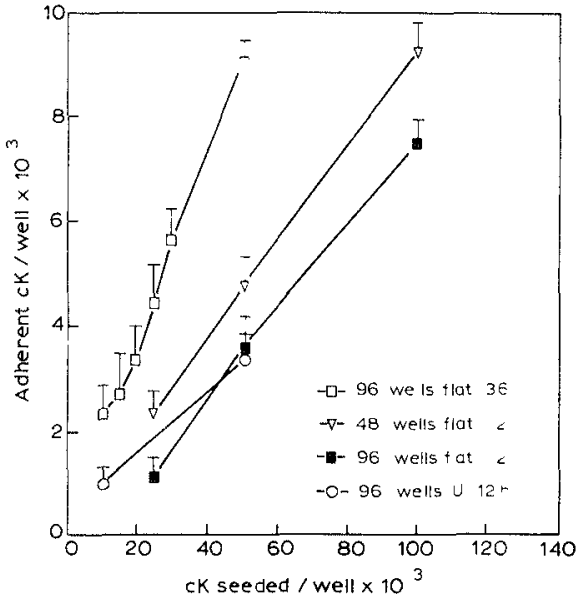

Fig 1 Effect of plate type and adhesion period on plating efficiency of keratmocytes seeded at various densities cK were seeded from 10 to $100 \times 10^{3}$ cells/well and incubated for $12 \mathrm{~h}$ in Costar (cat no 3548) 48 well flat-bottomed $(\nabla)$, Costar (cat no 3799) 96-well round-bottomed plates (O) and for $12 \mathrm{~h}$ (四) and $36 \mathrm{~h}(\square)$ in Gremer (cat no 655160) 96-uell flat-bottomed plates Numbers of adherent $\mathrm{cK} /$ well were measured as described in the matenals and methods section, mean values \pm $\mathrm{SE}$ of the 5-phcate measurements are plotted

\section{Measurement of the target cell number}

Measurement of the number of adherent $\mathrm{cK} /$ well was performed first, to determıne the efficacy of adhesion under the various seeding conditions studied to optimize the assay (Figs 1 and 2), and subsequently to routinely determine the exact target cell number present per well for each different $\mathrm{cK}$ culture used. In short, the following procedure was used The wells contanng the adherent $\mathrm{CK}$ to be counted, were washed three times with PBS, incubated for $20-30 \mathrm{~min}$ in $50 \mu 1$ of $0.25 \%$ trypsin (Difco), and after adding $150 \mu \mathrm{l}$ PBS $+1 \%$ BSA, the wells' contents were collected using a multichannel pipettor The wells were rinsed using another $100 \mu 1$ of PBS $+1 \%$ BSA per well. To obtain an accurate estimate of the adherent cell number per well, contents of 20-40 identical wells were pooled, centrifuged ( $8 \mathrm{~min}, 1000 \mathrm{rpm})$, adjusted to $05 \mathrm{ml}$ and counted undiluted

Under standard conditions, i.e., $10^{4} \mathrm{cK}$ seeded per well in Gremer 96-well flat-bottomed plates, incubated for $36 \mathrm{~h}, 16-29 \%$ of the seeded $\mathrm{cK}$ adhered depending on the keratmocyte culture used (data not shown) For the keratnocyte cell line used in all experiments shown here. ddhesion was $23 \%$, corresponding to $2.3 \pm 0.5 \times 10^{3}$ adherent $\mathrm{cK} /$ well

\section{Effector cells}

Human alloimmune CTL, sensitized selectively against the HLA-A $\mathrm{A}_{2}$ antigen (Horar et al., 1982) were cloned by limiting dilution. The HLA-A ${ }_{2}^{-}$ specific CTL clone 1E2 was used in the exper1ments after restımulation using allogenic feeder cells (Van de Griend et al., 1987). CTLs were cultured and tested in RPMI 1640 (Gibco) supplemented with gentamicin and $15 \%$ heat-inactivated pooled human serum (referred to as medium).

\section{${ }^{51}$ Cr release assay}

Wells containing adherent ${ }^{51} \mathrm{Cr}$-labeled $\mathrm{cK}$ were incubated in a volume of $200 \mu \mathrm{l}$ with effector cells (ranging from $15 \times 10^{4}$ to $15 \times 10^{4} \mathrm{CTLs} /$ well), with medium alone, or with medium containing a 5\% Triton X-100 solution, for measurement of experimental (ER), spontaneous (SR) and max1mal release (MR) respectively. Incubation with $5 \%$ Triton X-100 freed $90-95 \%$ of the total amount of ${ }^{51} \mathrm{Cr}$ incorporated in adherent $\mathrm{cK}$ (data not shown),

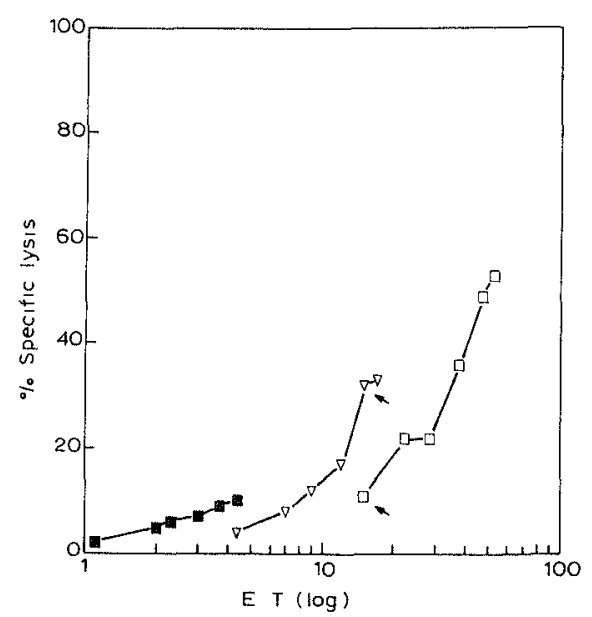

Fig 2 Effect of effector-to-target ratio (E T) and the absolute number of adherent $\mathrm{cK} /$ well on antigen specific lysis of ddherent CK HLA-A ${ }_{2}$-specific CTL clones were added at three different concentrations ( $1 \times 10^{4}, \nabla 4 \times 10^{4}$ and $\square 125 \times$ $10^{4} \mathrm{CTL} /$ well) to wells containing ddherent $\mathrm{cK}$ of an HLA-A + ve donor Densities of $\mathrm{cK}$ ranged from 23 to $90 \times 10^{3}$ adherent $\mathrm{cK} /$ well and had been generated by seeding $1-5 \times 10^{4}$ $\mathrm{cK} /$ well Mean values of $\%$ lysis of 5 -phicates $(\mathrm{SE}<15 \%)$ at resulting $\mathrm{E} T$ are presented per CTL concentration, 4 indicate different $\%$ lysis at $\mathrm{E} \mathrm{T}=15$ 
and therefore was consıdered appropriate for measurement of MR All measurements were carried out in 5-plicate The plates were centrifuged shortly to enhance cell-cell interaction (10 s, $2000 \mathrm{rpm})$ and incubated at $37^{\circ} \mathrm{C}$ for $4 \mathrm{~h}$ Thereafter, the plates were centrifuged for $5 \mathrm{~min}$ at $2000 \mathrm{rpm}$, supernatants were harvested using a collector system (Skatron SCS harvesting frames no 15772 , Norway) and radioactivity was counted in a Packard gamma counter Mean values and standard errors were calculated for all 5-plicate measurements of cpm released in experimental wells (ER), in wells for spontaneous release (SR) and for maximal release (MR) Relative spontaneous release $(\mathrm{SR} / \mathrm{MR} \times 100 \%)$ never exceeded $20 \%$ Percentage of specific lysis was determined using the following formula

\% specific lysis $=\frac{\mathrm{ER}-\mathrm{SR}}{\mathrm{MR}-\mathrm{SR}} \times 100 \%$

\section{Results}

\section{Optımization of the keratinocyte layers}

Prior to using adherent $\mathrm{cK}$ as target cells in the ${ }^{51} \mathrm{Cr}$ release assay it was important to establish optimum conditions for (a) cell adhesion, (b) ${ }^{51} \mathrm{Cr}$ labelıng, and (c) washing of the layers of $\mathrm{cK}$

Adhesion We assessed the effects on adhesion of the type of tissue-culture wells used, the duration of the incubation period and the cell density seeded As is shown in Fig 1, after $12 \mathrm{~h}$ incubation the plating efficiency (cK adhered/cK seeded $\times 100 \%$ ) was very similar for all types of wells tested (75-90\%) We selected Gremer 96 wells flat-bottomed microtitre for further use Prolonging the incubation time up to $36 \mathrm{~h}$ caused a two-fold increase in the number of adherent $\mathrm{cK}$ in these wells Under these seeding conditions reldtive variation of the 5-plicate samples in the number of adhered cK/well did not exceed $20 \%$, irrespective of the seeding density (Fig 1)

${ }^{5}$ Cr-labeling For the subsequent ${ }^{51} \mathrm{Cr}$ labeling of the $\mathrm{cK}$ adhered to the microtiter wells it was pursued to minimize the dmount of radioactive material needed The use of $2 \mu \mathrm{C} /$ well was considered acceptable and represented a 5 -fold reduction in the amount of $\mu \mathrm{C}_{1}$ used per well as compared to similar labeling procedures used for adherent fibroblasts (Russel et al, 1988) and endothelial cells (Miltenburg et al, 1988)

Washıng procedure To optimize the washing procedure of the labeled $\mathrm{cK}$ ( $1 \mathrm{e}$, to minimize the variance in adherent cells/well), two ways of removing the washing fluid were compared, namely the usage of a multichannel hand pipettor or decanting the fluid The variance in number of adherent cells in the 5-plicate wells did not differ signuficantly between the two methods, the latter method was chosen as standard procedure for reasons of efficiency (data not shown)

Optimization of the effector-target ratto and the absolute target cell number

To determine the effector-to-target ratio (E T) and the number of target cells optimal for lysis of cK in the adherent assay, both the cK seeding concentration and the effector cell concentration were varied Since cK have been shown to express the serologically defined HLA class I antıgens (Mauduit et al , 1987), we studied HLA-A ${ }_{2}$-specific lysis using the $\mathrm{A}_{2}$-specific CTL clone $1 \mathrm{E}_{2}$ as effector cells $\mathrm{cK}$ were seeded at densities ranging from $10^{4}$ to $5 \times 10^{4}$ per well of which $\pm 20 \%$ was found to be present as target cells after $36 \mathrm{~h}$ of incubatıon (see F1g 1) CTLs were added at concentrations ranging from $1 \times 10^{4}$ to $125 \times 10^{4}$ CTL/well As can be seen from Fig 2, the percentage of specific lysis increased with increasing $\mathrm{E} \mathrm{T}$, but was also affected by the absolute numbers of effector cells and adherent $\mathrm{cK}$ per well For example, at $\mathrm{E} T=15$, specific lysis was $33 \%$ at $4 \times 10^{4} \mathrm{CTL}$ and $26 \times 10^{3}$ adhered $\mathrm{cK} /$ well, as compared to $11 \%$ when $125 \times 10^{4} \mathrm{CTL}$ and $85 \times 10^{3} \mathrm{cK} /$ well were used This apparent infdvorable effect of high numbers of keratinocytes and effector cells on lysis could either be due to crowding of the effectors (which is not very likely at $125 \times 10^{4} \mathrm{CTL} /$ well) or to a less efficient exposure of $\mathrm{cK}$ to CTLs when $\mathrm{cK}$ cultures reach confluency Layers containing low numbers of adherent $\mathrm{cK}$ thus seemed to provide a more sensitive system for measurement of specific lysis

For purposes of standardisation of the assdy, the seeding density was set at $10^{4} \mathrm{cK} /$ well which corresponded to numbers of adherent $\mathrm{cK}$ ranging 


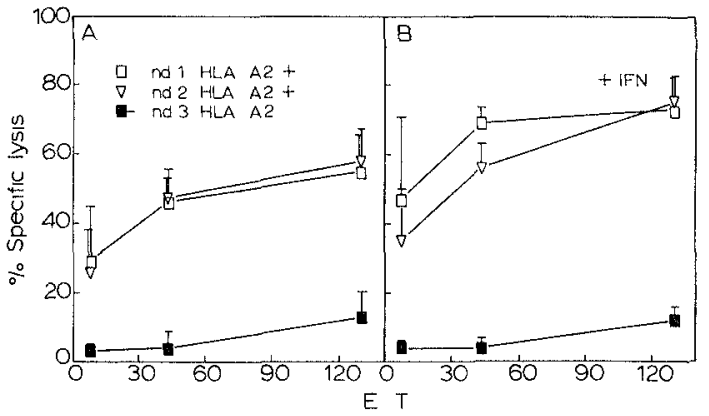

Fig 3 Antıgen specific lysis of untreated ( $F_{11} 3 A$ ) and rIFN treated (Fig 3B $250 \mathrm{U} / \mathrm{ml}, 20 \mathrm{hrs}$ ) $\mathrm{cK}$ of $3 \mathrm{HLA}$ typed donors 2 HLA $\mathrm{A}_{2}$ positive (ind 1, ind 2) and 1 HLA $\mathrm{A}_{2}$ negatıve (Ind 3) Layers of $\mathrm{cK}$ were standardly generated $\left(10^{4}\right.$ cK seeded per well 36 hrs adhesion in 96 wells Greıner no 655160 flatbottomed plates), clone 1E2 was used as effector (15-15 $\times 10^{4} \mathrm{CTL} /$ well) Values of \% specific lysis represent mean $\pm \mathrm{SE}$ of 3 serial expenments using sequentral subcultures (passage 1,2 and 3) of $\mathrm{cK}$ of the same donors, SE of $\%$ specific lysıs of the 5-plicate samples did not exceed 20\% (not shown)

from $16 \times 10^{3}$ to $29 \times 10^{3}$ per well for distunct cK cultures used (not shown)

\section{Antigen-specific lysts of $c K$ with and without IFN $\gamma$ pretreatment}

The assay was applied to study the susceptibility of human $\mathrm{cK}$ to lysis by CTLs directed to HLA class I antigens In addition, the effect of IFN- $\gamma$ on $\mathrm{CTL} /$ keratinocyte interaction was studied As can be seen in Fig $3 A$, HLA-A 2 specific CTLs showed dose-dependent lysis of $\mathrm{cK}$ of two HLA-A $\mathrm{A}_{2}$ positive individuals, whereas no lysis of HLA-A $\mathrm{A}_{2}$ negative $\mathrm{cK}$ was observed unless very high numbers of CTLs were used ( $<5 \%$ lysis at $\mathrm{E} T<100$ ) Premcubation of $\mathrm{cK}$ with rIFN- $\gamma$ increased the susceptubility of the HLA-A ${ }_{2} \mathrm{cK}$ to lysis from 45 to $70 \%$ for donor 1 , from 45 to $55 \%$ for donor 2, at $\mathrm{E} \mathrm{T}=42$ Aspecific lysis of $\mathrm{cK}$ of the HLA-A ${ }_{2}$ negative individual was not induced by IFN- $\gamma$ pretreatment $\left(\mathrm{F}_{1 \mathrm{~g}} 3 B\right.$ )

\section{Discussion}

Cultured human keratınocytes are frequently used as an in vitro target cell model to analyse mechanısms of CML of skin epithelial tissue Most investigators so far used suspensions of trypsinized cultured keratinocytes as target cells in the standard ${ }^{51} \mathrm{Cr}$, elease assay However, the susceptibulity of $\mathrm{cK}$ in this setting may differ significantly from that in situ due to changes in expression of cell surface molecules as a result of the trypsin treatment and the induction of differentiation of $\mathrm{cK}$ in suspension Additionally, high values of spontaneous ${ }^{51} \mathrm{Cr}$ release were commonly found to complicate the use of suspended ${ }^{51} \mathrm{Cr}$-labeled keratınocytes as targets for CML As reported here, we developed a cytotoxicity assay in which intact layers of cK in 96 well flat-bottomed microtiter plates are used as target cells Spontaneous ${ }^{51} \mathrm{Cr}$ release values of adherent $\mathrm{cK}$ in the $4 \mathrm{~h}$ assay are reduced to $15 \%$ of the Triton X-100 values Applying this assay for the analysıs of antigen specific CML of cK using cloned CTL specific for the HLA- $\mathrm{A}_{2}$ antigen and $\mathrm{cK}$ derived from three HLA-typed donors, we demonstrated that the assay was sensitive ( $45 \%$ specific lysis at $E \mathrm{~T}=40$ ), reproducible and provided no significant aspecific lysis (4\% at $E T=40$, see $F_{1} g$ 3) We found that pretreatment with IFN- $\gamma$ increased the susceptibility of $\mathrm{cK}$ to $\mathrm{A}_{2}$-specific lysis (Fig $3 B$ ) This presumably can be attributed to a IFN- $\gamma$-modulated induction of (a) a higher expression of HLA class I molecules (as was demonstrated by flow cytometric analysis, data not shown) and (b) de novo expression of ICAM-1 on $\mathrm{cK}$ (Dustin et al , 1988)

The finding that IFN- $\gamma$ treatment rendered $\mathrm{cK}$ more sensitive to CML was compatible with findings of other investigators who used suspended $\mathrm{cK}$ to assess antigen spectfic (Niederwieser et al , 1988, Kalısh, 1989) or non-specific lysis (Kalısh, 1989) In contrast, these groups did not find significant antigen specific lysis of basal, IFN- $\gamma$ untreated $\mathrm{cK}$, whereas we found lysis up to $50 \%$ of $\mathrm{cK}$ in this assay when using CTLs directed to HLA-A 2 (Fig $3 A$ ) or other HLA and non-HLA antigens (Van Els et al, submitted) We assume this discrepancy is due to differences in the cytolytic capicity and specificity of the antigen-specific $T$ cell lines and clones used

Our observations that $\mathrm{cK}$ were highly suscept1ble to antigen-specific CTLs in the absence of IFN- $\gamma$ pretreatment may put $\mathrm{CTL} /$ keratınocyte interactions in a new light Binding of CTLs to keratunocytes via the adhesion molecules LFA-1 and 1ts ligand ICAM-1 has been suggested to be crucial in cell-mediated lympholysis of keratinocytes (Dustm et al, 1988, Niederwieser et al, 
1988; Kalısh, 1989). However, since expression of ICAM-1 on basal, unstimulated $\mathrm{cK}$ has been demonstrated to be extremely low or absent (Dustin et al., 1988), our results may indicate that LFA1/ICAM-1 interaction is not an absolute requirement for CTL to lyse keratınocytes. If extrapolation to in vivo is allowed, CTL could target keratınocytes in inflamed skin, irrespective of ICAM-1 expression brought about by lymphokine production of infiltrated mononuclear cells. Whether in vivo the effector cells present in inflamed skın have sufficient cytolytic capacity to target keratinocytes without the additional 'help' of antigenindependent adhesion via ICAM-1, as demonstrated by our allo-CTL lines and clones in vitro, remains as yet unanswered.

We conclude that the cytotoxicity assay reported here represents a reproducible method to measure CML of intact layers of cultured keratinocytes The assay can serve to determine which cell-defined antigens are expressed by $\mathrm{cK}$ and what the modulatory effects of lymphokines are on effector cell/keratınocyte interactions. In this way it may provide a useful tool to understand the role of $\mathrm{CML}$ of keratinocytes in varıous $\mathrm{T}$ cellmediated cutaneous disorders.

\section{Acknowledgements}

The authors would like to thank the volunteering skin donors, Els Blokland and Jos Pool for technical advise and Dr. Rob Teepe for taking skin-biopsies.

This work was partially supported by the Dutch Foundation for Medical and Health Research (Medigon), the J.A Cohen Institute for Radiopathology and Radiation Protection (IRS), the Macropa Foundation and Greıner, The Netherlands.

\section{References}

Bagot, M, Heslan, M , Roujean, J C, Lebon, P and Levy, J P (1985) Human epidermal cells are more potent than periph eral blood mononuclear cells for the detection of weak allogenic or virus-specific primary responses in vitro Cell Immunol 94, 215

Brunner, K T, Mauel, J, Cerottını, J-C and Chapus, B (1968) Quantutative assay of the lytic action of immune lymphoid cells on ${ }^{51} \mathrm{Cr}$ labeled allogeneic target cells in vitro, inhibition by isoantibody and by drugs Immunology 14,1981

Dustun, M L, Singer, K H, Tuck, D T and Springer, T A (1988) Adhesion of T-lymphoblasts to epidermal keratinocytes is regulated by IFN- $\gamma$ and is mediated by intercellular adhesion molecule I (ICAM-I), J Exp Med 167, 1323

Faure, M, Dezutter Dambuyant, C, Schmiti, D, Gaucherand, $M$ and Thivolet, $J$ (1985) Langerhans cell induced cytotoxic $T$ cell responses against normal human epıdermal cell targets in vitro studies $\mathrm{Br} J$ Dermatol 113,114

Guyotat, D, Mauduıt, G, Chouvet, B, Kanitakıs, J, Vu Van, $\mathrm{H}$, Fiere, D and Thivolet, J (1986) A sequentral study of histological and immunological changes in the skin after allogenc bone marrow transplantation Transplantation 41 , 34040

Hora, S, Van der Poel, J J and Goulmy, E (1982) Differentral recognition of the serologically defined HLA-A ${ }_{2}$ ant1gen by allogenic cytotoxic $T$ cells Immunogenetics 16,135

Kalısh, R S (1989) Non-specifically activated human phenpheral blood mononucledr cells are cytotoxic for human keratınocytes in vitro $\mathrm{J}$ Immunol 142,74

Lampert, I A , Janossy, G , Suitters, A J , Bofill, M , Palmer, S Gordon-Smith, E, Prentice, H G and Alero Thomas, J (1982) Immunological analysis of the skin in graft versus host disease Clin Exp Immunol 50, 123

Liu, S C and Karasek, M (1978) Isolation and growth of adult epidermal keratinocytes in cell culture J Invest Dermatol 71,157

Maudut, G Vincent, C, Gielen, V, Faure, M, Demidem, A and Thivolet, $\mathrm{J}$ (1987) Expression of class I-MHC antigens by cultured human epidermis and epidermal allografts Tissue Antigens 29, 65

Miltenburg, A M M , Meyer-Paape, M E, Daha, M R and Paul, L C (1987) Endothelial cell lysis induced by lymphokıne-activated human peripheral blood mononuclear cells Eur J Immunol 17, 1383

Niederwieser, D, Aubock, J, Troppmair, J, Herold, M, Schuler, $G$, Boeck, G, Lot7, J, Fritsch, P and Huber, C (1988) IFN- $\gamma$ mediated induction of $\mathrm{MHC}$ antigen expression of human keratinocytes and its influence on in vitro allo Immune responses J Immunol 146, 2556

Norris, D A, Ryan, S B, Kissinger, RM, Fritz, KA and Boyce, S T (1985) Systemic comparison of antibody-medidted mechanisms of keratinocyte lysis in vitro J Immunol 135,1073

Rheınwald, J and Green, H (1975) Serıal cultuvation of strdıns of human epidermal keratinocytes The formation of keratonizing colonies from single cells Cell 6, 331

Rheinwald, G J and Beckett, M A (1980) Defective terminal differentiation in culture as a consistent and selectable character of malignant human keratinocytes Cell 22, 629

Russel, J H, Musil, L and McCulley, DE (1988) Loss of adhesion, a novel and distinct effect of the cytotoxic $T$ lymphocyte-target interaction J Immunol 140, 427

Van de Griend, R J, Van Krimpen, B A, Bol, S J L, Thompson, $A$ and Bolhus, RL (1984) Rapid expansion of human cytotoxic $T$ cell clones growth promotion by a hedlabile serum-component and by various types of feeder cells J Immunol Methods 76, 285 